The International Journal Of Engineering And Science (IJES)

|| Volume || 6 || Issue || 2 || Pages || PP 01-05 || 2017 ||

ISSN (e): $2319-1813$ ISSN (p): $2319-1805$

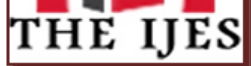

\title{
An Analysis on the Sanitation Condition and Suitable Measures to Achieve the Goal, A Case Study on Bankura District, West Bengal
}

\author{
Sujit Maji, Soumik Halder \\ Research Scholar, Department of Geography, Asutosh College, University Calcutta
}

\begin{abstract}
-
Bankura district is one of the backward districts of West Bengal in respect of sanitation. Here this article mainly dealing with the block wise sanitation status of Bankura district. Here, a sharp difference is found in development of sanitation among the blocks of Bankura. To find out the level of development in sanitation, Simple Composite Index (SCI) method has been employed and on the basis of this a zonation map has been prepared. The highest SCI value has found in Kotulpur block (5.03) and the lowest value has found in Ranibandh block (1.75).These values indicating the clear differences of sanitation coverage among the blocks. Out of 22 blocks 13 blocks have been identified as poor in respect of sanitation coverage. There are various reasons behind the lower accessibility of sanitation in these blocks, can be summarized are - Scarcity of water, contamination of ground water, inaccessibility, physiographic, literacy rate among people improper campaign for sanitation, lack of consciousness etc. To eradicating this sanitation related problems and promote a clean \& healthy life for the citizen, so many central sponsored programmes as well as state programmes have been taken to ensure the sanitation facility. This article deals with the problems related to sanitation, social impact of lower coverage of sanitation and remedial measures to curve down these difficulties.
\end{abstract}

Keywords: JE, MNB, S.C.I, CLTS, SLWM

Date of Submission: 09 January $2017 \quad$ Date of Accepted: 09 February 2017

\section{INTRODUCTION}

"Sanitation is more important than independence" - Mahatma Gandhi Ji

Sanitation is the practice of sterilization, or making sure that microbes or germs do not get into contact with humans, animals, food or water causing infections and sometimes fatal disease. It also involves disposing of waste properly, so it does not threaten the environment. So sanitation means people can spend a healthy life without illness in a healthy clean pollution free environment by taking some right procedures. Behind the development of any country or region there is always an important contribution of the local people or citizen of this country. Here the contribution means the physical and other cultural resources of people. So healthy and disease free citizen always indicates a strong developmental base of a country. The prime base of all the cultural resources is good health,_which controls all the other cultural resources like creatibility, working capability, thinking power, technology etc. Only healthy citizen can take the whole nation to the top of the development. A clear example as we can see the continuous development in most of the European and American countries. The reason behind is the major percentage of citizen are healthy in there. On the other hand it is also observable the stagnant developmental condition of most of the African and Middle American countries due to enormous health related problems. This problem drives a large scale displacement of people from one country to another. That is why Sanitation facility is a pillar of measurement of proper development in a region and obviously an important issue in recent times.

Here an attempt has been taken to analyze the sanitation condition of Bankura district of West Bengal. Generally Bankura district is known for its cultural heritage and also describe as the connecting link between the plains of Bengal on the East and Chotonagpur plateau on the West. In the district there is a good concentration of Schedule Caste and Schedule Tribe population (43\%) and simultaneously it is marked as a backward district (in respect of sanitation) of West Bengal. Health related problems are significantly high in this district. That is why Bankura district is selected in this study.

Study Area:

The study area is Bankura district of West Bengal. The district is situated between $22^{\circ} 38^{\prime}$ to $23^{\circ} 38^{\prime}$ North latitude and between $86^{\circ} 36^{\prime}$ to $87^{\circ} 46^{\prime}$ East longitude. The total geographical area covered by the district is 6882 square $\mathrm{km}$. Physiographically this district is dominated by plateau with residual hills and several dominated rivers like Damodar, Darakeswar, Kansabati, Silai etc playing a vital role for its developmental requirements. 
Objectives of the study:

* To analyze the block wise sanitation condition of Bankura district.

* To find out the reasons for development and backwardness of the blocks in the field of sanitation in Bankura district.

* Give an account on recent sanitation related programs or Governmental initiation for the district Bankura as well as state.

* To identify the major obstacles in the way of development of sanitation in Bankura district.

* And try to suggest some measures to eradicating those challenges.

\section{METHODOLOGY}

This work is mainly based on secondary data. Various secondary data have been collected from different Books, E sources etc. On the basis of this data a Simple Composite Index (S.C.I) method has been prepared for the blocks of Bankura district. This technique is very much useful to find out the block wise developmental condition of sanitation. For using the Simple Composite Index method three vital variables have been considered as i) Percentage of household having drainage connectivity ii) Percentage of household having safe \& moderately safe drinking water facility iii) Percentage of household having latrine facility. For safe and moderately safe drinking water the following criteria have been selected, these are tap water from treated and untreated source, covered well, hand pump and tube well.

For calculating this S.C.I value, the following formula have been used-

$$
\begin{array}{lr}
\Sigma \mathrm{V} 1 \div \Sigma \mathrm{N}=\overline{\mathrm{X}} & \multicolumn{2}{c}{\begin{array}{c}
\mathrm{V} 1=\text { Total value of first variable for the whole CD blocks. } \\
\mathrm{V} 1 \div \overline{\mathrm{X}}=\mathrm{V} 1 \mathrm{f}
\end{array}} \\
\Sigma \mathrm{V} 2 \div \Sigma \mathrm{N}=\overline{\mathrm{X}} & \Sigma \mathrm{V} 3=\text { Total value of second variable for the whole CD blocks. } \\
\mathrm{V} 2 \div \overline{\mathrm{X}}=\mathrm{V} 2 \mathrm{f} & \Sigma \mathrm{N}=\text { Total number of blocks in the district. } \\
\Sigma \mathrm{V} 3 \div \Sigma \mathrm{N}=\overline{\mathrm{X}} & \mathrm{V} 1=\text { Value of first variable for each block. } \\
\mathrm{V} 3 \div \overline{\mathrm{X}}=\mathrm{V} 3 \mathrm{f} & \mathrm{V} 2=\text { Value of second variable for each block. }
\end{array}
$$

Simple Composite Index value $=\mathrm{V} 1 \mathrm{f}+\mathrm{V} 2 \mathrm{f}+\mathrm{V} 3 \mathrm{f}$

$$
\overline{\mathbf{X}}=\text { Mean }
$$

V1f, V2f, V3f = Unit free values of each variables.

\section{Limitation of study:}

By taking these three parameters we can not clearly understand the overall situation of sanitation condition of Bankura district. Because these parameters mainly dealing with sanitation coverage only. But we cannot be found out how many house hold have utilized these facilities. Because facility utilization data and behavioral changes related data is almost unavailable. But these three parameters can able more or less to visualize the sanitation condition of Bankura district.

\section{Important aspects of Sanitation:}

The central issue of sanitation is the availability of water. Truly it can be said that there is no meaning of sanitation without water. In every possible steps of sanitation we can not ignore the importance of water. So development of sanitation in a region always depends on availability of water.

After ensuring the availability of water the next aspect is the quality of water. It is not only the matter of availability of water but the factor is that, the volume of safe water is available to the people. Because safe water can promotes healthy life and clean environment.

After that another aspect is providing the facilities related to sanitation like latrine facility, drinking water facility, drainage facility, waste disposal facility etc. These facilities can be considered as the basic needs of human life in recent times.

The last aspects are that proper use those facilities and keep your behavior in scientific way. Like using of latrine every day, washing hands with soap after use of latrine and before eating, disposing of waste in selected area, maintaining cleanness to the surrounding environment etc.

Out of these four aspects, if one aspect does not work properly then the whole sanitation process can not be fruitful. 
An analysis on the sanitation condition and suitable measures to achieve the goal, a case study on

Level of development of Sanitation Coverage in Bankura district:

Table 1: Calculation table for Simple Composite Index: Bankura district (2011)

\begin{tabular}{|c|c|c|c|c|c|c|c|c|}
\hline & & & & & \multicolumn{3}{|c|}{ Removal of biasness to scale } & \multirow[b]{2}{*}{$\begin{array}{l}\text { Total } \\
\text { (S.C.I. } \\
\text { value) }\end{array}$} \\
\hline $\begin{array}{l}\text { SL } \\
\text { No. }\end{array}$ & Blocks(N) & $\begin{array}{l}\% \text { of household } \\
\text { having drainage } \\
\text { connectivity(V1) }\end{array}$ & $\begin{array}{l}\% \text { of household } \\
\text { having safe \& } \\
\text { moderately safe } \\
\text { drinking water } \\
\text { facility (V2) }\end{array}$ & $\begin{array}{l}\% \text { of } \\
\text { household } \\
\text { having latrine } \\
\text { facility (V3) }\end{array}$ & V1 & $\mathrm{V} 2$ & V3 & \\
\hline 1 & Saltora & 9.47 & 70.13 & 9.14 & 0.67 & 0.80 & 0.54 & 2.01 \\
\hline 2 & Mejhia & 14.65 & 92.04 & 16.32 & 1.04 & 1.05 & 0.96 & 3.05 \\
\hline 3 & Gangajalghati & 9.58 & 83.36 & 14.08 & 0.68 & 0.95 & 0.83 & 2.46 \\
\hline 4 & Chhatna & 12.58 & 82.87 & 13.85 & 0.90 & 0.94 & 0.81 & 2.65 \\
\hline 5 & Indpur & 8.84 & 92.74 & 11.41 & 0.63 & 1.05 & 0.67 & 2.35 \\
\hline 6 & Bankura I & 16.45 & 91.14 & 16.00 & 1.17 & 1.04 & 0.94 & 3.15 \\
\hline 7 & Bankura II & 12.07 & 81.86 & 18.42 & 0.86 & 0.93 & 1.08 & 2.87 \\
\hline 8 & Barjora & 21.45 & 80.96 & 26.51 & 1.53 & 0.92 & 1.56 & 4.01 \\
\hline 9 & Sonamukhi & 20.25 & 93.23 & 18.77 & 1.44 & 1.06 & 1.10 & 3.60 \\
\hline 10 & Patrasayer & 16.54 & 96.74 & 22.38 & 1.18 & 1.10 & 1.32 & 3.60 \\
\hline 11 & Indus & 22.86 & 99.83 & 34.14 & 1.63 & 1.13 & 2.01 & 4.77 \\
\hline 12 & Kotulpur & 21.15 & 97.37 & 41.03 & 1.51 & 1.11 & 2.41 & 5.03 \\
\hline 13 & Jaypur & 19.88 & 97.55 & 27.43 & 1.42 & 1.11 & 1.61 & 4.14 \\
\hline 14 & Vishnupur & 22.97 & 94.62 & 15.22 & 1.64 & 1.07 & 0.89 & 3.6 \\
\hline 15 & Onda & 14.74 & 85.71 & 12.64 & 1.05 & 0.97 & 0.74 & 2.76 \\
\hline 16 & Taldangra & 11.80 & 84.36 & 15.08 & 0.84 & 0.96 & 0.89 & 2.69 \\
\hline 17 & Simlapal & 7.07 & 87.18 & 11.86 & 0.50 & 0.99 & 0.70 & 2.19 \\
\hline 18 & Khatra & 12.82 & 87.01 & 14.57 & 0.91 & 0.99 & 0.86 & 2.76 \\
\hline 19 & Hirbandh & 8.89 & 90.28 & 6.03 & 0.63 & 1.03 & 0.35 & 2.01 \\
\hline 20 & Ranibandh & 8.00 & 72.10 & 6.1 & 0.57 & 0.82 & 0.36 & 1.75 \\
\hline 21 & Raipur & 6.42 & 86.47 & 9.88 & 0.46 & 0.98 & 0.58 & 2.02 \\
\hline 22 & Sarenga & 10.56 & 88.90 & 13.55 & 0.75 & 1.01 & 0.80 & 2.56 \\
\hline & $\Sigma$ & 309.04 & 1936.45 & 374.41 & & & & \\
\hline & $\overline{\mathbf{I}}$ & 14.047 & 88.020 & 17.019 & & & & \\
\hline
\end{tabular}

By computing the S.C.I value and considering the relative position, the blocks have been divided into three categories as I) Good II) Moderate III) Poor and on the basis a zonation map also been prepared.

\section{Good Coverage:}

Those blocks having S.C.I value $>4.00$ are in this category. These are Barjora, Indus, Kotulpur and Joypur. The highest S.C.I value has found in the Kotulpur block as 5.03. These four blocks are situated in the North Eastern part of Bankura district and have good sanitation coverage. Because Physiographically Bankura district is undulating terrain with residual hills but these blocks are situated in more or less alluvial plain region and the major river Damodar is flowing near by this region. That is why both availability of river water and ground water, well accessibility, well connectivity, good infrastructure and consciousness of people are playing an important role for well sanitation coverage in this region.

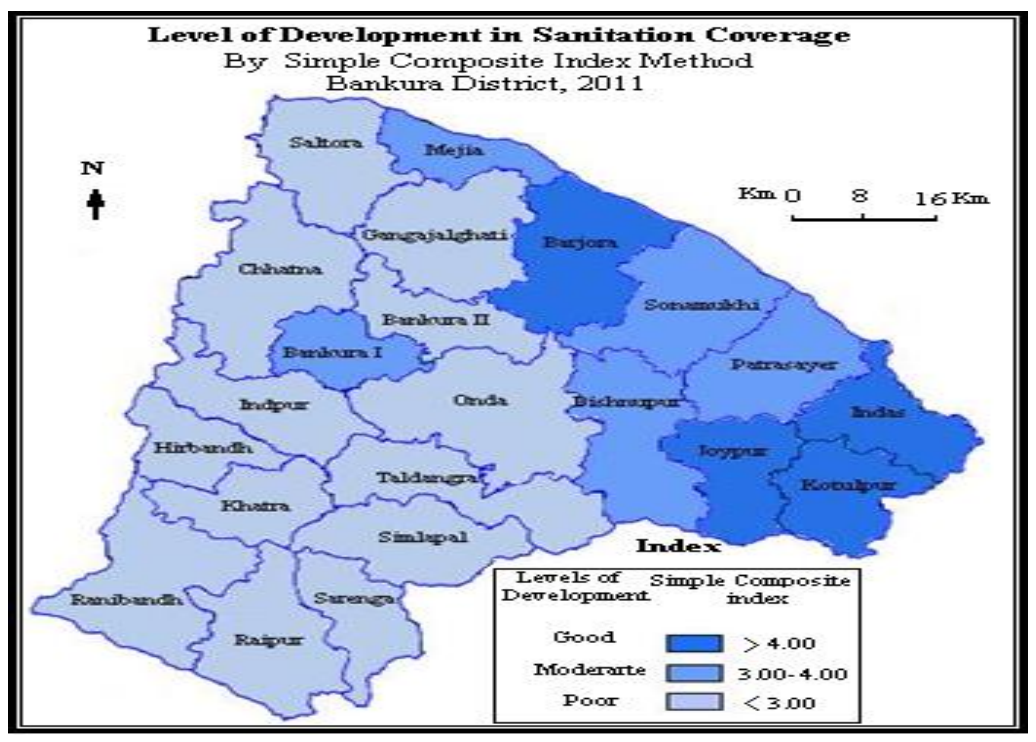




\section{Moderate coverage:}

Those blocks have S.C.I values from 3.00 to 4.00 are in this category. Five blocks are fallen in this category are Mejhia, Bankura I, Sonamukhi, Patrasayer, Vishnupur. These five blocks are also situated in the North Eastern part of the district. This region is relatively better in connectivity, drinking water facility and less undulating surface than Mid Western and Southern region of the district. For drinking water purpose Hand-boring is done for installation of tube wells in the of first two category region because of alluvial soil.

\section{Poor Coverage:}

Those blocks have S.C.I value is under 3.00 are in this category. Rests of blocks are in this group, these are Saltora. Gangajalghati, Chhatna, Indpur, Bankura II, Onda, Taldangra, Simlapal, Khatra, Hirbandh, Ranibandh, Raipur, Sarenga. These thirteen blocks cover the South Western and middle portion of the district with undulating plateau surface. Southern part of the district is very rugged and forest area. The lowest S.C.I value has been found in the southern most block, named Ranibandh as 1.75. These blocks are well lag behind due to low level accessibility, water scarcity, rugged surface, less drinking water facility and less consciousness among the people. Due to hard rock topography the installation of tube well is very problematic work in this region some times machine boring installation of tube well can not be done. In this region few blocks have a good concentration of schedule Tribe population as Ranibandh, Hirbandh, Raipur etc. Highest percentage of ST population is found in Ranibandh block as $47.07 \%$. But the problem is, this population has low level consciousness about sanitation and many of are illiterates.

\section{Major health related risks in Bankura district:}

Fluoride contamination in ground water is a major threat to Bankura district. Fluoride is found almost every where like in air, water and virtually all food stuff but it has a permissible limit to human body. Fluoride in ground water is found almost 10 blocks in Bankura district. In West Bengal Bankura district stands a vulnerable position in respect of fluoride contamination in ground water. The maximum concentration of fluoride is found in this district about $8.61 \mathrm{mg} / \mathrm{l}$. This is the main reasons for occurrences of several difficult health related diseases like - dental fluorosis, skeletal fluorosis, crippling skeletal fluorosis etc.

Malaria and diarrhea are the common public health problems in Bankura. The main malaria affected block is Ranibandh. About $70 \%$ of malaria cases coming from this block. Ranibandh is mainly hilly and tribal concentrate block and due to lack of awareness of the people this problem occurs.

Recently another serious problem was found in Bankura is JE (Japanese Encephalitis) virus, which take birth in the wet paddy and other agriculture field. This virus is transmitted through the bite of infected mosquitoes. Man is an accidental host and does play a role in JE transmission. This situation occur mainly water logging system which promote mosquito breeding. Bankura is the most JE affected district in West Bengal and cases reported 254 (2013) which is the highest in the State.

\section{Governmental Initiations to eradicating sanitation related problems:}

The Government of India has launched a program named Swachh Bharat Abhiyan to eradicating this sanitation problem in 2nd October 2014. But the West Bengal government has given this centrally aided programme a new name as - Mission Nirmal Bangla (MNB). This MNB is an offshoot of the Swachh Bharat Abhiyan, but conceived in a new avatar in West Bengal. The focuses and initiations taken by the MNB in West Bengal as well as in Bankura are:

The main focus is to shift from toilet as individual commodity to sanitation as public good.

The immediate target is at least one toilet unit for the boys and another for girls in the school. Because West Bengal is lag behind among the states in case of toilet unit for girls in the school.

For SLWM (Solid and Liquid Waste Management) programme at least one comprehensive SLWM facility is needed in every Gram Panchyet having 500+ household.

Another important focus is the complete use of ASHA, SHG and Anganwadi Workers for creating awareness among the people and acts as agents of behavioral changes in rural Bengal.

To achieve the required objectives the State Sanitation Cell and Communication \& Capacity Development unit (CCDU) jointly functioning in this field.

\section{Sanitation related problems in Bankura district:}

* The main problem in the district is scarcity of water. Having good quantity of rainfall (1400 mm/year) still this district known as drought prone district. This district faces a challenge of low ground water level due to porous lateritic soil and undulating surface. The water level varies in the district from $1.5 \mathrm{~m}$ to $22 \mathrm{~m}$.

* Another problem is that the physiography of the district. The dissected hilly topography is not favorable for ground water recharge and surface water also less in there.

* Majority of population have lack of knowledge about the use of those facilities and maintaining the right behavior. This problem is mainly strong in hilly tribal region of this district. 
* Inaccessibility also an important barrier in the way of sanitation development. The mid southern part of the district has low connectivity that is why some times frequent organizing of awareness camp is very difficult.

\section{Suggestions:}

$>$ Community Led Total Sanitation (CLTS) is an approach to achieve behavior change in mainly rural people by a process of 'triggering', leading to spontaneous and long term abandonment of open defecation practices. CLTS takes an approach to rural sanitation that works without hardware subsidies and that facilitates communities to recognize the problem of open defecation and take collective action to cleanup and become "open defecation free". In recent times Nadia district has been announced as first open defecation free district of west Bengal.

$>$ In the hilly region where the availability of water is low but rainfall amount $(1400 \mathrm{~mm} / \mathrm{year})$ is not a bad one. Rainwater Harvesting can be a good way to meet this need in that region.

$>$ For increasing the availability of surface water, digging of some big ponds can be done. But some times the hard rock topography creates difficulties to digging the ponds. In that case use of modern machineries can be fruitful.

$>$ Everyone should bring under the safe and clean drinking water coverage because it is the basic rights and needs also.

$>$ Over exploitation of ground water also need to be checked. One example can be cited here that Kotulpur block which is ranked $1^{\text {st }}$ in S.C.I method but due to over exploitation marked as black zone with respect to the availability of ground water.

$>$ More research should be done about the water profile, availability and quality of water. In short time duration the testing of water quality in villages is very much needed.

$>$ The main emphasis should be given on the awareness creation among the people about the advantages of using sanitation facilities and primitive behavioral change. In this case school education can play an important role. Because the educated next generation can play as an agent of behavioral change to the community.

\section{CONCLUSION}

From the discussion it can be said that truly Bankura district is designated as a poor district in respect of sanitation and health and there is a clear contrast in sanitation condition among the blocks also. The interesting matter is we have already assumed that the sanitation quality of first category blocks is well enough but that is not true. Because dividing the blocks into different categories is done only on the basis of their relative S.C.I value not any state or national level standard value. Almost all the blocks or Bankura as a whole stands in a poor position in respect of state level. The main problems behind that are the physiography and primitive tribal unconscious people in the district that is why to provide the basic facilities to individual is a big challenge for Government. But the government doing a good job after commence of Swachh Bharat Abhiyan. Government and different NGO are also doing the work on another big challenge like primitive behavioral change and learn them about the use of those facilities.

Education is the only way to bring the human behavior towards scientific way. This district and specially the backward blocks of the districts have low percentage of literate persons. Government has established many schools in this region and with the effect of Sarva Shiksha Abhiyan the enrolment ratio has increasing slowly. In the same way the sanitation related camp is necessary and this is needed very frequent in this region. In this regard local root level organization can play vital role. In case of community mobilization of tribal people where children can play a pivotal role by providing them (children) the good education \& right behavioral advises about the long \& healthy disease free life. Another interesting issue is that in urban or semi urban areas where the sanitation coverage is $100 \%$ and all the people are conscious about the sanitation where disease resisting power is gradually decreasing among the people due to food and working habit. That is why the germs and microbes can attack easily. In this regard the physical exercise should be incorporated to the sanitational procedures.

\section{REFERENCES}

[1]. Clean India: Clean Schools, a Handbook: Government of India.

[2]. District Census handbook Bankura, West Bengal, Census India 2011.

[3]. District Human Development Report: Bankura, Development and Planning Department, Government of west Bengal, 2007

[4]. Operational Guideline for Implementing Mission Nirmal Bangla.

[5]. Pal, A. (2016): “Geography of West Bengal - 2", New Grantha Bharati, Kadadi, Barhampur, Murshidabad.

[6]. Report on National Awareness Campaign on Japanese Encephalitis (JE)/ Acute Encephalitis Syndrome (AES) (23rd June to27th June 2014): WSSO, Public Health Engineering Department, Government of west Bengal. 